\title{
LOW AND NON-FAT ICE CREAM -LIKE AS AFFECTED WITH DIETARY FIBER
}

Emara, E. A* ; M. M. Abo-Srea ${ }^{*}$; K. M. K. Ayyad ${ }^{*}$ and T. H. EL- Sawah

Dairy Tech. Research Dept. animal production research institute, agriculture research center, Giza, Doky, Egypt.

"Dairy Dept. Fac. of Agric. Mansoura Univ., El mansoura, Egypt.

\begin{abstract}
The effect of two dietary fiber types (Konjac and maltodextrin) being added by different ratios $(0.1,0.2$ and $0.3 \%$ for the konjac, and 1,2 and $3 \%$ for the maltodextrin) as fat replacers on the properties of plain ice cream-like was investigated. Plain ice cream-like contained low contents of fat content (4,2 and $0 \%)$. All treatments were compared on their properties by control ice cream, which processed by the same method and contained $6 \%$ fat. Ice cream-like variants and control were stored at hardening temperature $\left(-18^{\circ} \mathrm{C}\right)$. All treatments and control were chemically, rhiologically and organoleptically analyzed in three replicates, and the average of three results was illustrated. Results showed that there isn't pronounced differences in the $\mathrm{pH}$ values among all treatments and control, Konjac treatments were of the lowest melting percent and overrun than other treatments, but had the highest sensory evaluation scores and viscosity values. On the other hand, using maltodextrin treatments resulted in the highest overrun and melting percent than Konjac treatments and control but it were not acceptable for the judges. So, results also indicate that using konjac dietary fiber improved the properties of ice cream and reduced its fat content with maintaining its good properties.
\end{abstract}

\section{INTRODUCTION}

While the first grade on the consumers' choice of food products is the taste, they also care about nutrition, ingredients and health as well. To achieve this target for consumers' demand, food companies started producing some of the health-oriented food products. Nowadays, dietary fibers are the most important in this trend (Ting, 2012). Ice cream is a frozen sweet dairy product which contains milk, and one or more of other dairy products (skim milk, skim milk powder, cream etc), sweeteners, stabilizers, emulsifiers, and flavoring agents. (Frost et al.2005; Guner et al. 2007a, b). Ice cream is a valuable food containing high nutritive components for human health. It has a delicious taste and cooling effect; hence it is commonly consumed during the summer by all ages of consumers (Demirci \& Simsek 1997). Investigations on ice cream technology focus on the development of new ice cream formulations. A lot of research works being reported in the literature related to the addition of new food ingredients for the development of new ice cream formulations. Different ingredients as soy protein (Friedeck et al. 2003), flaxseed oil, citrus fiber and hazelnut skin and flour (Dervisoglu 2006) were studied as an ingredients for the development of new ice cream formulation with preferred flavor, taste, and texture characteristics. Also, numerous ice cream formulations with functional properties have been 
developed, for example, probiotic ice cream and yogurt ice cream (Soukoulis \& Tzia 2008), ice cream enriched with dietary fiber (Cody et al. 2007 ). Konjac can be used in a wide range of application. It has the unique ability to create a thermo irreversible gel under high $\mathrm{pH}$ conditions after heating. This makes it ideal for a lot of food and dairy application processing that need the texture to remain throughout the processing. Konjac is commonly used to increase viscosity and to maintain pliability in dough and prevent cracking after freeze/ thaw cycle. it is also effective in many gluten free products. Also, konjac can play an important other functional, such as thicken and gelling agent, high viscosity and short texture, fat replacement, and increases moisture retention and binding agent in bars (Staninger, 2009). maltodextrin is produced as a result of starch fragmentation by enzyme and acid (Guzeler et al ., 2011). Maltodextrin gel can easily combine with liquid and solid fats and form a stable emulsion gel. Since it gives the same taste as fat, it helps foods to be broken easily into pieces in mouth. It is mostly used in margarine, mayonnaise, salad sauce, pastry and dairy products. In the production of energy reduced ice cream inulin, oligofructose, polydextrose, isomalt, lactitol, maltodextrin, milk protein concentrates, rice starch, and artificial sweeteners are usually as replacers of fat and sugar. The object of this work is, therefore, to investigate the possibility of using some dietary fiber types (konjac and maltodextrin) in different ratio as fat replacers on ice cream -like of low fat and free from fat, and investigate their effect on the ice cream characteristics.

\section{MATERIALS AND METHODS}

The pasteurized skim milk (protein $3.5 \%$, fat $<0.5 \%$ ) and fresh cream $60 \%$ fat was bought by Dairy Station Unit, Faculty of Agriculture, Mansoura University. Skim milk powder ( Mejerivagen I, S-59840 Vimmerby - Sweden) Commercial mixture of stabilizers and emulsifiers plass grad (Danisco Co., Copenhagen, Denmark), granulated and refined cane sugar (Eldakahlia sugar Co., egypt) were purchased from their suppliers and local market.

Konjac fiber and Maltodextrin were obtained from Ch. Hansen's Laboratories, Denmark.

For the preparation of ice cream, pasteurized skim milk (recommended as formula properties $\mathrm{w} / \mathrm{w} \%)$ and cream $\left(60 \%\right.$ fat) were wormed $\left(48{ }^{\circ} \mathrm{C}\right)$, then sugar $(18 \mathrm{w} / \mathrm{w} \%)$, dried skim milk powder (w/w\%), mixture of stabilizer, emulsifier and dietary fiber amount (w/w\%), were added, and the mix was agitated for $10 \mathrm{~min}$. Then, the mix was pasteurized using a batch pasteurizer (30 min at $69^{\circ} \mathrm{C}$ ), and mixed (laboratory mixer). For aging purposes the mix was cooled $\left(4.5^{\circ} \mathrm{C}\right)$ and aged at $\left(4^{\circ} \mathrm{C}\right)$ for $24 \mathrm{~h}$. After aging, the aeration process was performed by a batch freezer $\left(-5 \pm 0.5^{\circ} \mathrm{C}\right)$. Then, the ice creams were packed in $120 \mathrm{ml}$ plastic cups and stored at $-30^{\circ} \mathrm{C} / 24 \mathrm{hr}$ for hardening, followed by keeping in a freezer $\left(-22{ }^{\circ} \mathrm{C}\right.$ ) prior to analysis (Marshall et al. 2003). All formulations were treptical.

Total solids of ice cream samples were estimated according to (AOAC, 2005). The $\mathrm{pH}$ values of ice cream treatments estimated using a glass 
electrode $\mathrm{pH}$ meter type CG710, West Germany. In determining the $\mathrm{pH}$ values of ice cream, the electrode was immersed directly into the melted sample at $25^{\circ} \mathrm{C}$.

The ice cream mixes (aged for $24 \mathrm{~h}$ at $4^{\circ} \mathrm{C}$ ) were poured in a $500 \mathrm{ml}$ container and their apparent viscosity were determined using a Visco Elite rotational viscometer (BROOKFIELD, model RVDVE SERIAL NUMBER E 6531997 MADE IN USA. equipped with spindle No La6 at ambient $(20 \pm 0.5$ ${ }^{\circ} \mathrm{C}$ ) temperature (Marshall et al. 2003).

Hundred grams of cylindrical blocks of conditioned ice creams $\left(-22^{\circ} \mathrm{C}\right.$, $24 \mathrm{~h}$ ) were placed on sieve (Mesh No 6, Aperture3.35 mm, Testing Sieve) which was mounted on electric balance at $24 \pm 0.5^{\circ} \mathrm{C}$. The weight of melted ice cream was recorded every $10 \mathrm{~min}$ and the total amount of melted ice cream (during $60 \mathrm{~min}$ ) was used as percent for comparison purposes (Baer et al. 1999).

Overrun (\%) weight / weight was calculated as mentioned by Marshall et al.( 2003).

A number of 10 trained panelists (aged 20-40 years) were requested to evaluate encoded ice creams in terms of appearance, melting, flavour according to (Clarke 2004).

\section{RESULTS AND DISCUSSION}

Illustrated data in Table (1) show the differences in the total solids (T.S\%) content of ice cream and ice cream-like treatments. From these data control ice cream was of the highest T.S (36\%) among other treatments, followed by T5 $(34.5 \%)$. Konjac treatments had the lowest T.S content than control and other maltodextrin treatments. These changes on the T.S content might be due to the differences in the fat content and the higher doses of maltodextrin added on its treatments (T4, T5, and T6). Also, this increase of the examined fiber on the T.S content might be due to lose of the water content during the ice cream making. Similar results were reported by Goff and Richard (2013), who reported that there were many factors effect on ice cream total solids such as its constituents and processing temperature and freeze storage.

In addition, data presented in Table (1) also indicate the changes of some physiochemical properties of ice cream analogues. These data show that there were a high correlation between the dietary fiber type used in ice cream making and its physiochemical properties. This correlation was differed depending on the dietary fiber used. All ice cream analogues resulted in values higher of overrun than those recorded in the control. The increase in the overrun differed among konjac and maltodextrin treatments, whereas, the maltodextrin treatments possessed a higher overrun than konjac and control treatments. The increase in the overrun when maltodextrin was increased was lower. This decrease in the overrun values might be due to the increase of acidity of ice cream mix as a result to the enhancing effect of maltodextrin on the bacterial growth during the aging process. On the other hand, the increase on konjac addition ratio had pronounced effect on the overrun 
values until $(0.3 \%)$, which decreased its value. This might be due to the more doughy structure which limited the air corporation in the ice cream mix, thus, it causes a decrease on the overrun value. These results were in agreement with Thomas (1997), who reported that konjac fiber has good properties on suspension, elasticity, viscosity, and enhance dough and cracking properties.

Table (1): changes of overrun, melting, T.S\% of ice cream- like and control

\begin{tabular}{|c|c|c|c|c|c|c|c|c|}
\hline \multirow{2}{*}{ Treatment } & \multirow{2}{*}{ D.F } & \multirow{2}{*}{ D.F.\% } & \multirow{2}{*}{ T.S \% } & \multirow{2}{*}{$\begin{array}{l}\text { Overrun } \\
\text { (w/w \%) }\end{array}$} & \multicolumn{2}{|c|}{$\begin{array}{c}\text { Melting } \\
\left(24 \pm 0.5^{\circ} \mathrm{C}\right)\end{array}$} & \multicolumn{2}{|c|}{$\mathrm{pH}$} \\
\hline & & & & & fresh & $\begin{array}{c}15 \\
\text { days }\end{array}$ & Fresh & $\begin{array}{c}15 \\
\text { days }\end{array}$ \\
\hline$B$ & & 0 & 36.0 & 24,8 & 75 & 85,1 & 6.7 & 6.7 \\
\hline T1 & \multirow{3}{*}{ Konjac } & 0.1 & 33.5 & 25,7 & 63,25 & 64,9 & 6.65 & 6.66 \\
\hline T2 & & 0.2 & 32.0 & 24,9 & 52 & 57,6 & 6.7 & 6.7 \\
\hline T3 & & 0.3 & 30.6 & 24 & 50 & 43,3 & 6.7 & 6.7 \\
\hline T4 & \multirow{3}{*}{ maltodextrin } & 1 & 34 & 34,2 & 68.4 & 65,3 & 6.71 & 6.72 \\
\hline T5 & & 2 & 34.5 & 30,00 & 64 & 55,3 & 6.72 & 6.73 \\
\hline T6 & & 3 & 34.0 & 30.00 & 60 & 59,4 & 6.72 & 6.72 \\
\hline
\end{tabular}

D.F: dietary fiber

B: control ( $6 \%$ fat, $18 \%$ sugar, $0.5 \%$ stabilizer, $10 \%$ MSNF)

T1: (0.1 \% konjac, $4 \%$ fat, $18 \%$ sugar, $0.5 \%$ stabilizer, $10.5 \%$ MSNF).

T2: (0.2 \% konjac, $2 \%$ fat, $18 \%$ sugar, $0.5 \%$ stabilizer, $10.7 \%$ MSNF).

T3:( $0.3 \%$ konjac, $0 \%$ fat, $18 \%$ sugar, $0.5 \%$ stabilizer, $11 \%$ MSNF).

T4: (1 \% maltodextrin, $4 \%$ fat, $18 \%$ sugar, $0.5 \%$ stabilizer, $10.5 \%$ MSNF).

T5: (2 \% maltodextrin, $2 \%$ fat, $18 \%$ sugar, $0.5 \%$ stabilizer, $10.7 \%$ MSNF)

T6:( $3 \%$ maltodextrin, $0 \%$ fat, $18 \%$ sugar, $0.5 \%$ stabilizer, $11 \%$ MSNF)

Data in Table (1) show the changes of the melting properties of ice cream -like treatments and control. These data clear that all treatments with dietary fiber were of lower melting percent than that in control. Also konjac dietary fiber treatments was of the lowest melting percent than maltodextrin treatments. The addition ratio $0.3 \%$ konjac resulted in the lower melting values among other konjac treatments $(63.2,50$ for $0.3,0.1 \%$ respectively). These changes might be due to the increase of the water binding capacity and viscosity of all treatments, compared with control. These results came in harmony with those reported by Maryam etal., (2013), who reported that the use of any gums or dietary fibers enhance the melting properties of ice cream and desserts.

Moreover, there were no pronounced differences on the $\mathrm{pH}$ values on control and all ice cream -like treatments either on the beginning or during ice cream storage period.

Results presented in Table (2) show that at all speeds used on the viscosity determination all konjac treatments gained high values, compared with control, and reverse relationship was established between the ice cream fat content and its viscosity values. Also, positive relationship was found between the increase on the konjac ratio and the viscosity in all ice cream treatments. The addition of maltodextrin decreased the viscosity values, and was lower than other ice cream treatments and control. Moreover, there is more obvious effect with konjac addition than the differences on the fat content of ice cream treatments, whereas, T1 (zero \%fat and $0.3 \%$ konjac) 
were higher viscosity value $(480 / 2.4 \%$ at $50 \mathrm{rpm})$ than T3 (4\% fat and $0.1 \%$ konjac) $(260 / 1.3 \%$ at $50 \mathrm{rpm})$. On the other hand, this effect reversed in the maltodextrin treatments, whereas T4 (zero \%fat and 3\% maltodextrin) have the lower viscosity value (140/0.7at $50 \mathrm{rpm})$ than T6 (4\% fat and $1 \%$ maltodextrin)(200/1 \% at $50 \mathrm{rpm})$. The same results show that the low fat and Konjac treatments had high viscosity values than other treatments, which contain high fat and low konjac ratio, so, T1 gained $480 / 2.4 \%$ at $50 \mathrm{rpm}$ compared with T3 which have $260 / 1.3 \%$ which recorded at the same speed. These results might be due to the strong ability effect of the konjac on the gelling web which induces the viscosity progress; moreover, this effect became more pronouncing when the milk fat is present. In addition, the lowering effect of maltodextrin on viscosity might be due to the lowering ability of maltodextrin on the formation of gelling web and viscosity progress. These results are in agreement with Soukoulis etal.,(2009).

Table (2): changes on viscosity values of control and ice cream-like treatments (Temp/25 $\mathrm{c} /$ spendel 26$)$.

\begin{tabular}{|l|c|c|c|}
\hline \multirow{2}{*}{ Treatment } & \multicolumn{3}{|c|}{ Speed/rpm } \\
\cline { 2 - 4 } & $\mathbf{5 0}$ & $\mathbf{6 0}$ & $\mathbf{1 0 0}$ \\
\hline B & $220 / 1,1 \%$ & $200 / 1,2 \%$ & $160 / 1,6 \%$ \\
\hline T1 & $480 / 2.4 \%$ & $430 / 2,6 \%$ & $330 / 3,3 \%$ \\
\hline T2 & $400 / 2 \%$ & $370 / 2,2 \%$ & $290 / 2,9 \%$ \\
\hline T3 & $260 / 1.3 \%$ & $230 / 1,4$ & $190 / 1.9$ \\
\hline T4 & $140 / 0,7 \%$ & $120 / 0,7 \%$ & $90 / 0,9$ \\
\hline T5 & $140 / 0,7 \%$ & $130 / 0,8 \%$ & $120 / 1,2 \%$ \\
\hline T6 & $200 / 1 \%$ & $180 / 1,1 \%$ & $150 / 1.5 \%$ \\
\hline
\end{tabular}

Table (3): Changes of organoleptic parameters of ice cream throughout storage

\begin{tabular}{|l|c|c|c|c|c|}
\hline \multirow{2}{*}{ Treatments } & $\begin{array}{c}\text { Storage } \\
\text { period/days }\end{array}$ & $\begin{array}{c}\text { Appearance } \\
(\mathbf{3 0})\end{array}$ & $\begin{array}{c}\text { Melting } \\
\mathbf{( 3 0 )}\end{array}$ & $\begin{array}{c}\text { Flavour } \\
(\mathbf{4 0})\end{array}$ & $\begin{array}{c}\text { Total } \\
(\mathbf{1 0 0})\end{array}$ \\
\hline \multirow{2}{*}{$\mathrm{B}$} & fresh & 25 & 25 & 38 & 88 \\
\cline { 2 - 6 } & 15 & 26 & 27 & 38 & 91 \\
\hline \multirow{2}{*}{ T1 } & fresh & 30 & 28 & 36 & 94 \\
\cline { 2 - 6 } & 15 & 30 & 29 & 37 & 96 \\
\hline \multirow{2}{*}{ T2 } & fresh & 29 & 28 & 36 & 93 \\
\cline { 2 - 6 } & 15 & 29 & 29 & 36 & 94 \\
\hline \multirow{2}{*}{ T3 } & fresh & 26 & 26 & 38 & 90 \\
\cline { 2 - 6 } & 15 & 27 & 26 & 37 & 90 \\
\hline \multirow{2}{*}{ T4 } & fresh & 25 & 22 & 33 & 80 \\
\cline { 2 - 6 } & 15 & 24 & 23 & 34 & 81 \\
\hline \multirow{2}{*}{ T5 } & fresh & 26 & 25 & 36 & 87 \\
\hline \multirow{2}{*}{ T6 } & 15 & 27 & 25 & 36 & 88 \\
\cline { 2 - 6 } & fresh & 25 & 25 & 37 & 87 \\
\cline { 2 - 6 } & 15 & 26 & 26 & 38 & 90 \\
\hline
\end{tabular}


Data presented in Table (3) show the differences in the organoleptic properties of ice cream- like treatments and control. Data reveal that all ice cream like treatments gained higher organoleptic scores than control specially konjac treatments. Also, the differences in the appearance parameter were higher than other organoleptic parameters, followed by melting properties. Moreover, obviously differences were found among konjac and maltodextrin treatments in all organoleptic parameters either on fresh or stored product. These differences among konjac, maltodextrin treatments and control ice cream might be due to their changes on the strength of water binding ability and its viscosity. Data in the same Table appear that the progress in the storage period of ice cream had positive effect on all organoleptic properties and this might be as a result to the effect of hardening process and its enhancing effect on the gel web and the transformation of more free water for binding water. In addition, the illustrated data in this Table reflected that the changes of konjac ratios were more effective on the organoleptic properties than the changes in the fat content on ice cream -like treatments, whereas, T1 (0\% fat and $0.3 \%$ konjac) gained total scores (94), when compared with T3 (4\% fat and $0.1 \%$ konjac) which gained (90) in fresh ice cream. Moreover, maltodextrin treatments gained the lowest organoleptic scores than other treatments and control. This might be related with the slight progress on the acidity of its treatments and the off flavour aroma which appeared on its treatments in all sensory evaluation intervals.

\section{CONCLUSION}

The addition of konjac fiber and maltodextrin during ice cream making enhances its characteristics such as melting, overrun and viscosity and gives it more brightness on colour and more palatability in taste.

\section{REFERENCES}

Cody, T. L., Olabi, A., Petingell, A. G., Tong, P. S., and Walker, J. H. (2007). Evaluation of rice flour for use in vanilla ice cream. Journal of Dairy Science, 90, 4575-4585.

Demirci, M. and Simsek, O. (1997). Süt İşleme Teknolojisi, Hasad Yayıncılık Ltd. Şti. Rebel Ofset, Istanbul, $246 \mathrm{pp}$ (Turkish).

Dervisoglu, M. (2006). Influence of hazelnut flour and skin addition on the physical, chemical and sensory properties of vanilla ice cream. International Journal of Food Science and Technology, 41, 657-661.

Friedeck, K. G., Karagul-Yuceer, Y., and Drake, M. A. (2003). Soy protein fortification of a low-fat dairy-based ice cream. Journal of Food Science, 68, 2651-2657.

Frost, M. B., Heymann, H., Bredie, W. L. P., Dijksterhuis, G. B., and Martens, M. (2005). Sensory measurement of dynamic flavour intensity in ice cream with different fat levels and flavourings. Food Quality Preference, 16, 305-314. 
Goff. H. Douglas and Richard W. Hartel (2013).ice cream structure. Ice cream, book chapter, Springer US, pp :313-352

Guner, A., Ardic, M., Keles, A., and Dogruer, Y. (2007b). Production of yoghurt ice cream at different acidity. International Journal of Food Science and Technology, 42, 948-952.

Guner, A., Ardic,M., Keles, A., and Dogruer, Y. (2007a). Characterisation of ice cream containing flaxseed oil. International Journal of Food Science and Technology, 41, 946-953.

Guzeler, N., Kacar, A. and Say, D. (2011). Effect of milk powder, maltodextrin and polydextrose use on physical and sensory properties of low calorie ice cream during storage. Akademik Gıda, 9(2): 6-12.

Maryam B. Parvar and H. Douglas Goff (2013). Basil seed gum as a novel stabilizer for structure formation and reduction of ice recrystallization in ice cream. Dairy Sci. \& Technol, 93:273-285

Soukoulis, C., and Tzia, C. (2008). Impact of the acidification process, hydrocolloids and protein fortifiers on the physical and sensory properties of frozen yogurt. International Journal of Dairy Technology, 61, 170-177.

Soukoulis, C. and Tzia, Constantina (2009). Enrichment of ice cream with dietary fiber: Effects on rheological properties, ice crystallization and glass transition phenomena. Journal of food chemistry vol. 115 (2).

Staninger, H. (2009). Nano modified food starch and the therapeutic use of essential oils and oil blends. Polish Journal of Food and Nutrition Sci., 57(3):151-159.

Thomas W. R. (1997). Konjac gum. Thickening and Gelling Agents for Food. Book chapter, pp :169-179.

Ting- Ning lin (2012). Sensory analysis, instrumental analysis and consumers' acceptance towards multifunctional ice cream. Ph D. Thesis, faculty of the graduate school, university of Missoun.

Clarke C (2004). The science of ice cream. The Royal Society of Chemistry (RSC), London, pp 104-134.

Marshall RT, Goff HD and Hartel RW (2003) Ice cream, 6th edn. Kluwer Academic and Plenum, New York, pp 11-54, 149-168, 295-324.

Baer RJ, Krishnaswamy N and Kasperson KM (1999) Effect of emulsifiers and food gum on non-fat ice cream. J Dairy Sci 82(7):1416-1424. 
تأثير استخدام الالياف الغذائية علي صفات الايس كريم المنخفض والخالي الدهن

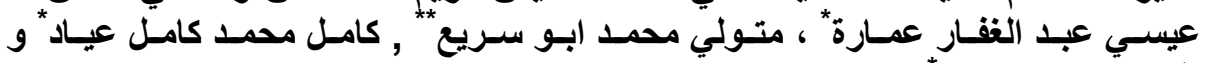

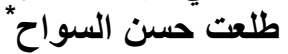
* قسم بحوث تكنولوجيا الالبان ـ معهد بحوث الانتاج الحيواني ـ مركز البحوث الزراعية ـ الاقي ـ

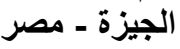
* قسم الالبان - كلية الزراعة - جامعة المنصورة - المنصورة - مصر

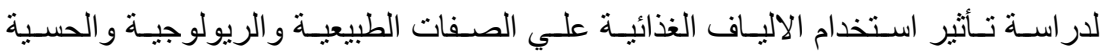

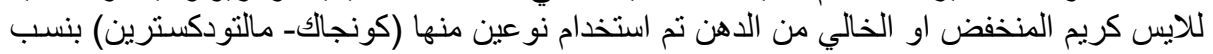

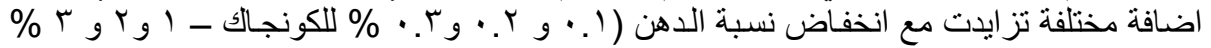

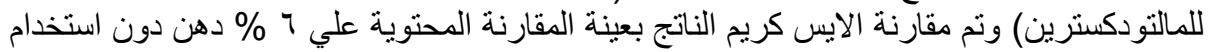

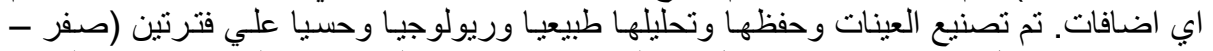

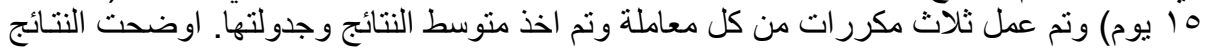

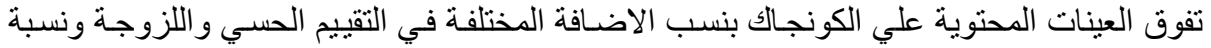

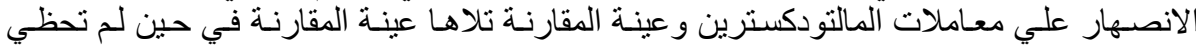

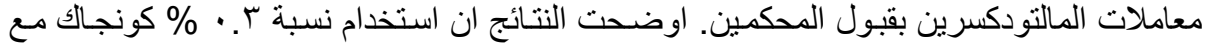

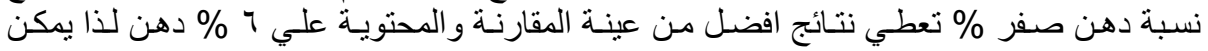

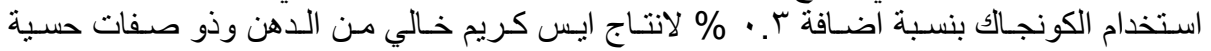
وريولوجية وطبيعية جيدة. 